\title{
About the editors and authors
}

\section{EDITORS}

Carsten Lund Pedersen is Assistant Professor in the Department of Marketing at Copenhagen Business School. His research interests include business-to-business (B2B) digitization processes (i.e., how do B2B firms become digital, and how do they commercialize data?), the autonomy of frontline employees (i.e., how do frontline employees make decisions on their own, without asking for permission from immediate managers?), and empathy-based marketing (i.e., can marketing be interpreted as an empathetic process?). His work has been published in Industrial Marketing Management, Psychology \& Marketing, and MIT Sloan Management Review, as well as in digital articles available through HBR.org, SMR, CMR Insights, Nature, and NatureIndex, among others. Carsten earned his doctoral degree (industrial Ph.D. in collaboration with TDC A/S) with a thesis on the collective wisdom of frontline employees, in 2016. As a part of his degree program, he was a visiting fellow at the MIT Sloan School of Management. Carsten received the EliteForsk Travel Grant in 2015 and the DSEB Dissemination Prize in 2017, and he was nominated for a DSEB teaching prize in 2018. Prior to joining academia, Carsten was employed by Telenor and Cybercity, where he gained practical experience with marketing, customer relationship management, and digitization.

Adam Lindgreen studied engineering, chemistry, food science \& technology, and physics in Denmark and abroad prior to earning his doctoral degree in Marketing at Cranfield University. He has held academic positions with top universities in Belgium, New Zealand, the Netherlands, and the United Kingdom. He is Professor of Marketing and Head of the Department of Marketing at Copenhagen Business School.

In addition to his articles in leading academic journals, he has published 29 practitioner-relevant books. He has taught marketing-related courses (undergraduate, graduate, Ph.D., and executive levels), and he has been awarded the Dean's Award for Excellence in Executive Teaching.

Adam's interdisciplinary research interests include business and industrial marketing, consumer marketing, corporate social responsibility, sustainability, and evolutionary psychology. In his spare time, he is an avid genealogist and has published widely in leading academic journals on this topic. His research has been funded by the Danish Research Academy, the (UK) Higher Education Innovation Fund, the (US) Marketing Science Institute, and the National Fund for Scientific Research (Belgium). His research has won several awards. Much of Adam's research is done in collaboration with companies.

Adam is a member of the International Scientific Advisory Panel of the New Zealand Food Safety Science and Research Centre (a partnership among government, industry organizations, and research institutions). He also is a member of the Chartered Association of Business 
Schools' Academic Journal Guide (AJG) Scientific Committee in the field of marketing, as well as the Det videnskabelige Råd for Lex.dk.

Thomas Ritter holds a Master of Business Engineering and a doctoral degree (Dr.rer.pol.) from the University of Karlsruhe. After a position at the University of Bath, he joined Copenhagen Business School where he is Professor of Market Strategy and Business Development in the Department of Strategy and Innovation. At Copenhagen Business School, he served as Associate Dean for the Bachelor of International Business program and the full-time MBA program, and he was Academic Director of the CBS Competitiveness Platform.

Thomas's research focuses on business relationship management, data-driven business development, business model innovation, and strategy. He has published numerous articles in leading outlets, including Journal of Service Research, Journal of Product Innovation Management, Industrial Marketing Management, and Harvard Business Review, amongst others. He is mentioned on the Stanford Top 2\% Scientist list in 2020 and is the only author with three papers on the IMM Classics list. His work has been intensively downloaded and cited. Currently, he is heading two research projects funded by the Danish Industry Foundation that investigate the integration of products, services, and data, as well as the use of customer data for growth.

Thomas is a highly regarded educator. He teaches mainly on the MBA and executive level, and he contributes to executive and non-executive board programs. He has more than 20 years' experience working with consulting firms of all sizes and from many industries.

Torsten Ringberg is Professor of Marketing at Copenhagen Business School. He has an MBA, M.A. (Psychological Anthropology), and Ph.D. in Marketing (Penn State University). His work has appeared in top-tier international academic business journals, such as Journal of Marketing, Journal of Consumer Research, Journal of Consumer Psychology, Management Studies, and Annals of Tourist Research. He regularly reviews for leading journals and presents at leading international consumer behavior conferences. He has won two Best in Practice Awards from the American Marketing Association/Milwaukee, based on two strategic consulting projects for large US corporations that uncovered managers' and consumers' subconscious mindsets. He publishes on topics such as embodied cognition, mental mindsets, the use of big data, and how managerial mindsets affect the successful adoption of digital technologies. Torsten has received funding from the Danish Research Council and the Danish Industrial Foundation.

Torsten is actively engaged in helping mid- to large-size organizations optimize their managers' strategic mindsets relative to customer preferences. He is member of the Danish Competition Council, which ensures fair competitive market conditions for both online and physical businesses. Torsten has served as an expert witness in important court cases, regularly evaluates large funding applications for researchers involved with small and medium-sized enterprise projects, and heads the Torben and Alice Frimodt Fund (supporting projects in sciences, environmental non-governmental organization, and humanitarian causes).

\section{AUTHORS}

Henrik Andersen has 35 years' experience in global consultancy, where he has advised firms from a broad range of industries. In 2002, he founded Andersen\&Partners Management 
Consulting, prior to which he was a partner at PricewaterhouseCoopers Management Consulting for the EMEA region. Henrik's focus is on strategic planning, organizational and cultural change, customer relationship management, and customer segmentation. His work in these areas has been published in books and numerous articles.

Poul Houman Andersen is Professor of Marketing at Aalborg University Business School and head of the marketing and sales group. He is also part-time Professor of Supply Chain Management at the Norwegian University of Science and Technology. Poul received his degree from Aarhus University. He has published across several disciplines, including marketing, strategy, purchasing and supply management, and research methodology.

Shirley Y. Coleman is Technical Director of the Industrial Statistics Research Unit, School of Mathematics, Statistics and Physics, Newcastle University, where she works on data analytics in small and medium-sized enterprises and specializes in statistical and machine learning techniques applied to company data. Shirley publishes in trade and academic journals and is co-editor of several books. She is a chartered statistician and actively mentors early career statisticians while also developing relationships with business and industry.

Annie V. Dang is a law student at Georgetown University Law Center. She was previously a research associate at Harvard Business School, focusing on entrepreneurship, innovation, and small business, as well as an investigative analyst in the Major Economic Crimes Bureau of the Manhattan District Attorney's Office. Annie received her Bachelor of Arts from Harvard University and has published with the National Bureau of Economic Research.

Heikki Karjaluoto is a Professor in the University of Jyväskylä School of Business and Economics, where he heads the Department of Marketing. Heikki received his D.Sc. degree from the University of Jyväskylä. He has published in Business Strategy and the Environment, Computers in Human Behavior, European Journal of Marketing, Industrial Marketing Management, and Internet Research, among others.

Christian Kowalkowski is Professor of Industrial Marketing at Linköping University and is affiliated with the Centre for Relationship Marketing and Service Management at Hanken School of Economics in Helsinki. Christian's research interests include service growth strategies, service innovation, and business-to-business (B2B) subscription business models. His work has been published in journals such as Industrial Marketing Management, Journal of Business Research, and Journal of Service Research. He is the servitization editor for the Journal of Service Management, associate editor of the Journal of Services Marketing, and advisory board member of Industrial Marketing Management. He is the co-author of Service Strategy in Action: A Practical Guide for Growing Your B2B Service and Solution Business (www.ServiceStrategyInAction.com, Service Strategy Press, 2017), the leading book for industry executives on how to navigate the transition from a goods-centric to a service-savvy business model.

Paul Matthyssens is Professor of Strategic Management at the University of Milano-Bicocca, DEMS. He received his doctorate in Applied Economics from the University of Antwerp in 1986. Known for his work on service-oriented strategy, his research interests also include business and industrial marketing, value innovation, global strategy, and purchasing strategy. From 2013 to 2018, Paul was Dean of AMS. He received the Full-Time Master Teacher Award 
in 2014. As an avid visiting professor, Paul has taught at several universities internationally, including Copenhagen Business School, Stockholm School of Economics, and Fordham University. He has also published around 100 articles in top academic journals, such as Journal of Management Studies, Strategic Organization, Industrial Marketing Management, Long Range Planning, Technovation, Journal of Business \& Industrial Marketing, Psychology \& Marketing, International Marketing Review, and Journal of Purchasing \& Supply Management. He also serves on the editorial boards of different international magazines.

Joel Mero is Assistant Professor of Marketing at the University of Jyväskylä School of Business and Economics. Joel received his D.Sc. degree from the University of Jyväskylä. He has published in Industrial Marketing Management, Electronic Markets, and Marketing Management Journal, among others. Some of the research conducted for the chapter he contributed to this volume was performed before August 2020, when he acted as Assistant Professor in LUT University School of Business and Management.

Karen G. Mills is a Senior Fellow at the Harvard Business School, where she is part of the entrepreneurship faculty. She served in President Barack Obama's Cabinet as the Administrator of the US Small Business Administration from 2009 to 2013 and was a member of the President's National Economic Council. Karen is the President of MMP Group and a longtime venture capitalist and private equity investor. Her current research focuses on small businesses, US competitiveness, and innovation. Karen is the author of the book Fintech, Small Business \& the American Dream, as well as several papers on small business lending and supply chains.

Dana Minbaeva is Professor of Strategic and Global Human Resource Management in the Department of Strategy and Innovation, and Vice-President for International Affairs, at Copenhagen Business School. Her research on strategic international human resources management has appeared in top international journals, numerous book chapters, and reports. Dana is a co-founder of Nordic Human Capital Analytics (www.nhca.dk).

Camilla Nellemann works for the Manufacturing Academy of Denmark (MADE), where she manages a research project on digital learning factories. She was previously a postdoctoral researcher at Copenhagen Business School, funded by MADE. Camilla holds a doctorate in International Management from Rikkyo University, and advises businesses and private individuals on Japanese culture.

Frederikke Amalie la Cour Nygaard has a Master's degree in Business Administration and Economics, with a specialization in human resources management, from Copenhagen Business School. Throughout her career, she has worked with data and personnel processes in various organizations. Frederikke is currently the human resources analyst at the Danish Ministry of Climate, Energies and Utilities.

Sena Ozdemir is Senior Lecturer in Marketing at Lancaster University Management School. Her research spans a range of subjects, including strategic alliances in new product development (NPD), interfirm cross-functional NPD team integration, global NPD, the use of big data analytics (including customer and marketing analytics) and other digital technologies for innovation, and social and sustainable innovation. Sena's cross-disciplinary research areas include marketing and business-to-business marketing, strategy, operations, and innovation, designed 
to advance scholarship on NPD practices and performance. Her research informs scholars of marketing and innovation, practitioners such as marketing and product development managers, and innovation policy makers. She currently serves as an editorial board member for the Journal of Business-to-Business Marketing. Her publications have appeared in journals such as Industrial Marketing Management, Journal of Business Research, British Journal of Management, International Marketing Review, Journal of Business-to-Business Marketing, Qualitative Market Research: An International Journal, and Innovation: Organization \& Management.

Torben Pedersen is Professor of International Business at Bocconi University, Milan. His research interests focus on the interface between strategy and international management, and he has published more than 100 articles and books related to the managerial and strategic aspects of globalization. His research has appeared in prominent journals such as Academy of Management Journal, Strategic Management Journal, Journal of Management, Journal of International Business Studies, Journal of Management Studies, and Organization Science. In addition, Torben has written more than 25 teaching cases, published by case clearing houses or in teaching-oriented books. He is a Fellow of the Academy of International Business, European International Business Academy, and Strategic Management Society.

Helle Rootzén is the CEO and founder of andhero, which she started in 2020. Until 2020, she was Professor of Learning Technology and Digitalization at the Technical University of Denmark (DTU), leader and founder of the Center for Digital Learning Technology, and director of DTU Compute. Helle received her doctoral degree from DTU. She is one of the Danish Academy of Technical Sciences' "Digital wise men" and a member of several boards. She has published in Statistics in Medicine, International Conference on Computer Supported Education, European Conference on e-Learning, Acta Oncologica, and the European Consortium for Mathematics in Industry, among others.

Pernille Rydén is Dean of Education at the IT University of Copenhagen. She received her doctoral degree from CBS in research strategic cognition, with a particular focus on the human and organizational conditions for success with digital technologies in private and public organizations. Pernille has published in outlets such as California Management Review, Industrial Marketing Management, and Journal of Interactive Marketing and is also the lead author of the book Disrupt Your Mindset to Transform Your Business with Big Data.

Vania Sena is the Chair of Enterprise and Entrepreneurship and Director of the Centre for Regional Economic and Enterprise Development (CREED) at the University of Sheffield. She established the ESRC Business and Local Government DRC (based at the University of Essex) in 2013, and she is a co-investigator in the ESRC Productivity Insights Network (PIN). Her first degree was awarded cum laude by the University of Naples, Federico II; her postgraduate studies in Economics were carried out at the University of York, where she was awarded both an M.Sc. and the D.Phil. Vania's research focuses mainly on econometric analyses of the determinants of productivity growth, at both micro and macro levels, with an emphasis on innovation, human capital, and intellectual property. She also has an interest in the use of alternative methods (e.g., linear programming analysis) for measuring productivity. Her most recent research addresses the relationship among innovation activities, trade secrets, and total factor productivity. Her work has been published in Journal of Economic Literature, Journal 
of Corporate Finance, Journal of Banking and Finance, Small Business Economics, Journal of Comparative Economics, The Economic Journal, Scandinavian Journal of Economics, European Journal of Operational Research, and Oxford Bulletin of Economics and Statistics and Regional Studies, among others. Vania has received funding from several bodies, including ESRC, Nuffield, NESTA, Leverhulme Trust, IPO, UKTI, and the British Academy. She is a member of the Operational Society General Council and the OR Analytics Development Group. She has been a visiting fellow at Harvard University and Rutgers University.

David Sörhammar is Associate Professor of Marketing at Stockholm Business School, Stockholm University. His research interests include service growth strategies, cocreation, and innovations. David's research has been published in journals such as Industrial Marketing Management, Journal of Business Research, and Marketing Theory.

Bieke Struyf is a doctoral candidate at the University of Antwerp and researcher at the Antwerp Management School. She focuses on identifying value-creating strategies, barriers, and critical success factors that contribute to effective digital transformation in the Flemish manufacturing industry. With her multilevel, multidisciplinary research, under the supervision of Paul Matthyssens and Wouter Van Bockhaven, Bieke investigates the impact on and mobilization of individual employees, the organization, and its surrounding ecosystem.

Tanja Tammisalo is a graduate researcher from LUT University who currently works as a digital marketing specialist at iProspect.

Bård Tronvoll is Professor of Marketing at Inland Norway University of Applied Sciences and at CTF-Service Research Center at Karlstad University. He is a member of the editorial advisory board for Journal of Service Management, and his work has been published in Journal of the Academy of Marketing Science, Journal of Service Research, Journal of Business Research, European Journal of Marketing, Journal of Service Management, and Marketing Theory. Bård's research interests include marketing theory, service innovation, customer complaining behavior/service recovery, and digitalization.

Jan Trzaskowski is Law Professor at Copenhagen Business School. For more than two decades, he has dealt with legal and regulatory aspects of information technology, with a particular focus on data and consumer protection law. Jan has a keen interest in human decision-making, persuasive technology, and the societal implications of information technology.

Wouter Van Bockhaven is a researcher, Lecturer, and Assistant Professor at the Antwerp Management School. He received his doctoral degree in Applied Economics from the University of Antwerp in 2014. His research focuses on how firms can develop innovation networks to tackle institutional and social barriers that prevent the creation of shared value. Combining qualitative and quantitative approaches, Wouter aims to address the real-life challenges experienced by managers in pharmaceutical, medical devices, machine building, and steel industries. His work has been published in Industrial Marketing Management and Journal of Business and Industrial Marketing. 
'This is a very timely book. SMEs with limited resources have to understand the power of big data and ensure that they are not left behind by the large platforms. This book is insightful and rigorous. It features multiple perspectives and guidelines provided by a group of excellent experts. It's a very valuable guide for practitioners and a great teaching resource for faculty and students.'

Markus Reihlen, Former Vice President, Professor of Strategic Management, and Principle Investigator of the Digital Entrepreneurship Project, Leuphana University of Lüneburg,

Germany

'Creating actual digital innovation roadmaps for SMEs based on big data beyond the hype of the words is of great value. I welcome this contribution to increasing competitiveness for SMEs through data, digital competencies, and innovative solutions that increase companies' insight into customers ' needs and challenges.' Per B. Brockhoff, Professor, Head of Department, M.Sc., Ph.D., R, Technical University of

Denmark

'I have often seen how data is given too little attention when companies undertake digitalization efforts. That is a shame, since access to high quality data is like having a superpower, and this superpower is accessible to any business that is willing to do the work. Good to see a book that focuses on the opportunities for small and medium-sized businesses!'

Pernille Erenbjerg, Board Member at Genmab, Nordea, Nordic Entertainment Group and Millicom, Denmark

'The importance of big data competence cannot be overstated, and should not be out of the reach of smaller firms. Small and medium-sized enterprises should be able to increase their success by building big data capabilities and creating data-driven growth. This book shows how smaller firms have developed big data competence and digitization capability,

implemented artificial intelligence techniques, and identified customer growth potential through customer insight analysis. The authors provide realistic guidance for implementation using real-life successful examples. In sum, this book provides a roadmap to small and medium-size enterprises that wish to facilitate their adoption of big data capabilities and become fully digitally enabled.' C. Anthony Di Benedetto, Fox School of Business, Temple University, USA

'I congratulate the authors for focusing on how small and medium-sized businesses can make the most of big data based small investments and fast experimentation for quick wins. Agility is key, and this excellent book exactly shows how SMEs can move fast - to win fastin the data space.'

Wolfgang Ulaga, Senior Affiliate Professor of Marketing at INSEAD \& Director of the Marketing \& Sales Excellence Initiative (MSEI), France

'Through my active involvement in SMEs, I see the struggles and the successes of SMEs' data utilization journeys. I very much hope that this book will inspire many executives on how to successfully engage in data-driven business development.'

Jan Damsgaard, Professor of Digitalization, Copenhagen Business School and Board member at SME Denmark \& National Digital Expert Advisor, Denmark 
